\title{
Preferential migration of regulatory $T$ cells mediated by gliomasecreted chemokines can be blocked with chemotherapy
}

\author{
Justin T. Jordan · Wei Sun · S. Farzana Hussain • \\ Guillermo DeAngulo $\cdot$ Sujit S. Prabhu $\cdot$ \\ Amy B. Heimberger
}

Published online: 20 September 2007

(C) Springer-Verlag 2007

\section{Erratum to: Cancer Immunol Immunother DOI 10.1007/s00262-007-0336-x}

The original version of this article unfortunately contained a mistake. There is an error regarding the dose of BCNU utilized to treat U-87 cells- the correct concentrations are
0.28 and $2.8 \mu \mathrm{M}$ in Fig. 5a, b. Additionally, in the "Discussion" section, the greatest CNS penetration of temozolomide and BCNU, respectively (not Gliadel), were reported as $24 \pm 4 \mu \mathrm{M}$ in the CSF [18] and $9.3 \mathrm{nM} / \mathrm{gm}$ within brain tissue [9]. The authors apologize for the error and the incorrect citation.

The online version of the original article can be found under doi:10.1007/s00262-007-0336-x.

J. T. Jordan · W. Sun · S. F. Hussain · S. S. Prabhu •

A. B. Heimberger $(\bowtie)$

Department of Neurosurgery, Unit 442,

The University of Texas M. D. Anderson Cancer Center,

1515 Holcombe Blvd, Houston, TX 77030, USA

e-mail: aheimber@mdanderson.org

G. DeAngulo

Department of Pediatrics, Unit 87,

The University of Texas M. D. Anderson Cancer Center,

1515 Holcombe Blvd, Houston, TX 77030, USA 